\title{
Emotional intelligence, attachment styles and medical education
}

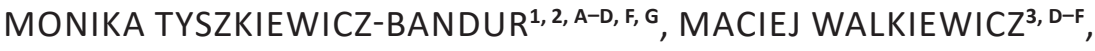 \\ MAŁGORZATA TARTAS ${ }^{3,}$, , JUSTYNA BANKIEWICZ-NAKIELSKA ${ }^{1,2, \text { E }}$
}

${ }^{1}$ Center of Psychological Training for Physicians COHERENCE, Szczecin, Poland

${ }^{2}$ Faculty of Public Health, Pomeranian Medical University, Szczecin, Poland

${ }^{3}$ Faculty of Psychology, Medical University of Gdansk, Poland

A - Study Design, B - Data Collection, C - Statistical Analysis, D - Data Interpretation, E - Manuscript Preparation, F - Literature Search, G - Funds Collection

Summary Background. For many patients, the doctors' empathy is just as important as their clinical experience.

Objectives. The goal of this paper is to describe the level of emotional intelligence and attachment styles of medical students and health science students. Another aim is to describe the differences between the emotional intelligence and attachment styles of male and female students.

Material and methods. 328 students of the Faculty of Medicine and the Faculty of Health Science of the Pomeranian Medical University of Szczecin, Poland, took part in the research. Emotional intelligence was assessed with the use of the Schutte Self Report Emotional Intelligence Test (SSEIT). The attachment styles were assessed with the use of the Relationship Questionnaire (RQ) - an adaptation of Hazan \& Shaver's Adult Attachment Questionnaire.

Results. The students of the Faculty of Medicine showed a lower level of emotional intelligence in comparison to the students of the Faculty of Health Science. Generally, all students with a secure attachment style who participated in the research manifested a higher level of emotional intelligence. According to expectations, females obtained a higher level of emotional intelligence than males. Conclusions. Students of the Faculty of Medicine shall be introduced to psychological prevention with special emphasis on developing emotional relations with others.

Key words: emotional intelligence, physicians, medical students, medical education, professional role.

Tyszkiewicz-Bandur M, Walkiewicz M, Tartas M, Bankiewicz-Nakielska J. Emotional intelligence, attachment styles and medical education. Fam Med Prim Care Rev 2017; 19(4): 404-407, doi: https://doi.org/10.5114/fmpcr.2017.70127.

\section{Background}

For many patients, the doctors' empathy is just as important as their clinical experience. One of the most popular and opinion-forming medical journals (Journal of General Internal Medicine) proposed a model of practicing medicine defined as "Relationship - Centered Care" (RCC). This model is based on the assumption that "all illness, care and healing processes occur in relationships of an individual with self and with others. (...) RCC can be defined as care in which all participants appreciate the importance of their relationships with one another. RCC is founded upon four principles: 1) that relationships in health care ought to include the personhood of the participants, 2) that effect and emotion are important components of these relationships, 3) that all health care relationships occur in the context of reciprocal influence, and 4) that the formation and maintenance of genuine relationships in health care is morally valuable. In RCC, relationships between patients and clinicians remain central, although the relationships of clinicians with themselves, with each other and with community are also emphasized" [1]. The contemporary practice of medicine seems to be still far from postulated assumptions.

The term emotional intelligence (EI) describes the ability to: "1) perceive emotions in oneself and others, as well as in objects, art, stories, music and other stimuli; 2) facilitate thought to generate, use and feel emotion as necessary to communicate feelings or employ them in other cognitive processes; 3 ) un- derstand emotions to understand emotional information, how emotions combine and progress through relationship transitions and to appreciate such emotional meanings; and 4) manage emotions - the ability to be open to feelings and to modulate them in oneself and others so as to promote personal understanding and growth [2]. Emotional intelligence is connected with performance in the medical profession. A high level of EI decreases stress [3] and positively correlates with teamwork $[4,5]$, physician job satisfaction [6-8] and patient satisfaction with medical treatment [9]. The results concerning the relationship between $\mathrm{El}$ and gender in medical professions are contradictory [10], but most data shows that El is higher in the female population [11]. What is more, the El level among physicians positively correlates with their professional experience [12]. The positive aspect is that medical graduates achieve a higher level of El than those who apply to medical schools [10].

The attachment theory was originally developed by Bowlby. The theory provides a foundation for understanding the development of emotional attachment in children, conceptualized as an affectionate bond that they form with a caregiver, to whom they turn to in times of distress [13].

In line with Bowlby's theory, Bartholomew describes four models of attachments styles in interpersonal relationship [14]:

1. Those with Secure Attachment Style manifest a positive and realistic self-image and are capable of developing mature relationships and relying on others in difficult situations. They are more likely to find efficient 
strategies of managing problems by focusing on difficulties and searching for support. They activate their attachment system by thinking about the availability of love and support. Such an attitude brings them relief and decreases the tension connected with stress [15].

2. Those with Preoccupied Attachment Style manifest low self-esteem, and at the same time, they tend to overestimate others. They are not capable of using support from other people.

3. Those with Fearful Attachment Style manifest not only a negative self-image, but also are reluctant to trust others. They are afraid of intimacy and avoid social contact. Moreover, they suffer from an intense fear of being rejected. Although it is their desire to be in a close relationship with other people, they may resist closeness because they fear the consequences.

4. Those with Dismissing Attachment Style tend to deny their needs and desires of being in close relationships. They avoid closeness, demonstrate high self-esteem and a low propensity to trust others, and at the same time, they preserve their independence and are immune to being hurt. Their outstanding traits are a low level of communicative skills and an incapability of taking advantage of social support [15].

\begin{tabular}{|c|c|c|c|}
\hline & & $\begin{array}{l}\text { MODEL OF SELF } \\
\text { (Dependence) }\end{array}$ & \\
\hline & & $\begin{array}{l}\text { Positive } \\
\text { (Low) }\end{array}$ & $\begin{array}{l}\text { Negative } \\
\text { (High) }\end{array}$ \\
\hline $\begin{array}{l}\text { MODEL } \\
\text { OF OTHER } \\
\text { (Avoidance) }\end{array}$ & $\begin{array}{l}\text { Positive } \\
\text { (Low) }\end{array}$ & $\begin{array}{l}\text { SECURE } \\
\text { Comfortable with } \\
\text { intimacy and } \\
\text { autonomy }\end{array}$ & $\begin{array}{l}\text { PREOCCUPIED } \\
\text { Preoccupied } \\
\text { with relationships }\end{array}$ \\
\hline & $\begin{array}{l}\text { Negative } \\
\text { (High) }\end{array}$ & $\begin{array}{l}\text { DISMISSING } \\
\text { Dismissing of } \\
\text { intimacy } \\
\text { Counter- } \\
\text {-dependent }\end{array}$ & $\begin{array}{l}\text { FEARFUL } \\
\text { Fearful } \\
\text { of intimacy } \\
\text { Socially avoidant }\end{array}$ \\
\hline
\end{tabular}

Figure 1. Model of attachment

Source: Bartholomew K, Horowitz LM. Attachment styles among young adults: a test of a four-category model. J Pers Soc Psychol 1991; 61: 226-244.

Bowlby believes that attachment patterns and internal working models of relationships are relatively stable throughout one's life span, although Waters' longitudinal study suggests that attachment style could be disrupted by major life events [16]. The important point here is that a person's response in situations of 'threat', e.g. a life-threatening illness, is related to their internal working models, as such that they may, for example, seek to reduce anxiety by finding closeness or by avoidance of the stimulus responsible for fear.

Research on psychotherapy has suggested that the ability to build an effective alliance with patients may be related to the therapist's attachment style [17]. There is a significant relation between the 'secure' and 'insecure' attachment style in clinical psychologists and their clinical practices [18]. 'Insecure' psychologists experience more difficulty in their practice than their 'secure' counterparts, and they feel less supported at work and have reported that their work interferes with their personal lives. Other research data shows that 'secure' therapists are able to attend to clients' underlying needs, in contrast to 'insecure' ones who responded more to the most obvious presentation of needs [19].

The above results indicate that research on attachment styles as a factor for effective alliance with patient seems to be a promising area for research in the medical professions.

\section{Objectives}

The goal of this paper is to describe the level of emotional intelligence and attachment styles of medical students and health science students. Another aim is to describe the differences between the emotional intelligence and attachment styles of male and female students.

\section{Material and methods}

\section{Participants}

In the research, 328 students of the Pomeranian Medical University in Szczecin, Poland, participated: 181 students of the Faculty of Medicine ( $M=21 \pm 0.8$; Female 65\%) and 147 students of the Faculty of Health Sciences studying the following fields: Midwifery, Nursing, Paramedic Science, Health Promotion, Cosmetology Dietetics ( $\mathrm{M}=22 \pm 2$; Female 89\%). The respondents completed questionnaires in their free time and were guided by an individual who was not their lecturer (response rate $328 / 430=76 \%$ ).

\section{Measures}

1. The Schutte Self Report Emotional Intelligence Test (SSEIT) is a 33 item self-report measure of emotional intelligence designed to map onto the Salovey and Mayer model of El. Items of the test relate to the three aspects of El:

a) appraisal and expression of emotion,

b) regulation of emotion,

c) utilization of emotion [20].

2. The Relationship Questionnaire (RQ) is an adaptation of Hazan \& Shaver's Adult Attachment Questionnaire. It yields dimensional scores on four categories of attachment styles: secure, preoccupied, fearful and dismissing. Participants rated each statement based on a seven point Likert scale ranging from: 1 = not at all like me, to 7 = very much like me [14].

\section{Statistics}

The variables of normal distribution are presented with a mean and a standard deviation. The variables with non-normal distribution - with median, minimal and maximal values. The Kołmogorov-Smirnov test was used to assess distribution. Nominal data is presented as percentages. The statistical significance of differences between the two groups was processed with the $t$-Student test - verifying the hypothesis of equal levels of emotional intelligence in the analyzed groups of students. The Kołmogorov-Smirnov test was used in cases where conditions of performing the $t$-Student test were not satisfied. The percentage of results between attachment styles and faculty was compared using the chi-square test. The critical level of significance was determined as $\alpha \leq 0.05$. Microsoft Excel and StatSoft Statistica 10 PL was used for statistical analysis.

The research did not involve any handling of sensitive personal data or clinical procedures and, therefore no other special consent was required. The Bioethics Committee of the Pomeranian Medical University of Szczecin (Poland) reviewed and approved researches concerning patients and clinical procedures. All students participating in the research expressed a written consent to participate in the study.

\section{Results}

The students of the Faculty of Medicine obtained a significantly lower level of emotional intelligence measured with the SSEIT questionnaire than the students of the Faculty of Health 


\begin{tabular}{|c|c|c|c|c|}
\hline & $\begin{array}{l}\text { Emotional Intelligence } \\
\text { (Schutte Self Report Emotional } \\
\text { Intelligence Test - SSEIT) }\end{array}$ & $\begin{array}{l}\text { Emotional Intelligence } \\
\text { (Schutte Self Report Emotional } \\
\text { Intelligence Test - SSEIT) }\end{array}$ & $t$ [df] & $p$ \\
\hline Faculty & $\begin{array}{l}\text { Faculty of Medicine } \\
n=181 \\
M \pm S D=126.26 \pm 12.16 \\
M d n=128 ; \text { Min }=70 ; \operatorname{Max}=162^{*}\end{array}$ & $\begin{array}{l}\text { Faculty of Health Sciences } \\
n=147 \\
M \pm S D=130.26 \pm 13.25\end{array}$ & $\begin{array}{l}2.512 \\
{[d f=326]}\end{array}$ & 0.012 \\
\hline Gender & $\begin{array}{l}\text { Male } \\
n=79 \\
M \pm S D=124.94 \pm 14.42\end{array}$ & $\begin{array}{l}\text { Female } \\
n=249 \\
\mathrm{M} \pm \mathrm{SD}=129.04 \pm 14.35\end{array}$ & $\begin{array}{l}2.212 \\
{[d f=326]}\end{array}$ & 0.028 \\
\hline $\begin{array}{l}\text { Attachment style } \\
\text { (Relationship Questionnaire } \\
\text { - RQ) }\end{array}$ & $\begin{array}{l}\text { Insecure } \\
n=16 \\
\mathrm{M} \pm \mathrm{SD}=124.17 \pm 14.50\end{array}$ & $\begin{array}{l}\text { Secure } \\
n=163 \\
M \pm S D=131.97 \pm 13.34\end{array}$ & $\begin{array}{l}5.069 \\
{[d f=326]}\end{array}$ & $<0.001$ \\
\hline
\end{tabular}

* variables without normal distribution (The Kołmogorov-Smirnov test was used to assess distribution. The critical level of significance was determined as $\alpha \leq 0.05)$.

\begin{tabular}{|c|c|c|c|c|}
\hline & $\begin{array}{l}\text { Emotional Intelligence } \\
\text { (Schutte Self Report Emotional } \\
\text { Intelligence Test - SSEIT) }\end{array}$ & $\begin{array}{l}\text { Emotional Intelligence } \\
\text { (Schutte Self Report Emotional } \\
\text { Intelligence Test - SSEIT) }\end{array}$ & $t[\mathrm{df}]$ & $p$ \\
\hline Faculty of Medicine & $\begin{array}{l}\text { Male } \\
n=63 \\
\mathrm{M} \pm \mathrm{SD}=124.03 \pm 15.27\end{array}$ & $\begin{array}{l}\text { Female } \\
n=118 \\
\mathrm{M} \pm \mathrm{SD}=127.45 \pm 15.03\end{array}$ & $\begin{array}{l}t=1.449 \\
{[\mathrm{df}=179]}\end{array}$ & 0.864 \\
\hline Faculty of Health Science & $\begin{array}{l}\text { Male } \\
n=16 \\
M \pm S D=128.50 \pm 10.03\end{array}$ & $\begin{array}{l}\text { Female } \\
n=131 \\
\mathrm{M} \pm \mathrm{SD}=130.47 \pm 13.61\end{array}$ & $\begin{array}{l}t=0.561 \\
{[\mathrm{df}=145]}\end{array}$ & 0.216 \\
\hline
\end{tabular}

\begin{tabular}{|c|c|c|c|c|}
\hline $\begin{array}{l}\text { Attachment style } \\
\text { (Relationship Questionnaire } \\
\text { - RQ) }\end{array}$ & $\begin{array}{l}\text { Faculty of Medicine } \\
n=181 \\
\text { frequency, } n(\%)\end{array}$ & $\begin{array}{l}\text { Faculty of Health Sciences } \\
n=147 \\
\text { frequency, } n(\%)\end{array}$ & $\begin{array}{l}\mathrm{Chi}^{2} \text { Pearson } \\
\text { [df] }\end{array}$ & $p$ \\
\hline Secure & 75 (42\%) & 87 (59\%) & \multirow{2}{*}{$\begin{array}{l}\mathrm{Chi}^{2}=10.2221 \\
{[\mathrm{df}=1]}\end{array}$} & \multirow[t]{2}{*}{0.001} \\
\hline Insecure & $106(58 \%)$ & 60 (41\%) & & \\
\hline
\end{tabular}

Sciences. Generally, female students demonstrated a higher level of emotional intelligence than their male counterparts. According to the results obtained in the Relationship Questionnaire (RQ), the students were divided into two groups: $R Q-S e-$ cure - those manifesting Secure Attachment Style, and RQ - Insecure - those with other attachment styles, i.e. preoccupied, fearful and dismissing.

The level of emotional intelligence in both groups was then tested with the use of $t$-Student and Kołmogorov-Smirnov tests. It turned out that those with Secure Attachment Style have a higher level of emotional intelligence than the students demonstrating RQ - Insecure Attachment Styles (Table 1).

There is no difference in the level of emotional intelligence between male and female students inside faculties (Table 2).

The students of the Faculty of Medicine obtained a significantly higher level of Insecure/Secure Attachment Style than the students of the Faculty of Health Sciences (Table 3).

\section{Discussion}

For medical and healthcare professionals, good contact with a patient is just a tool and a key for efficient outcomes. However, the students of the Faculty of Medicine obtained a significantly lower level of emotional intelligence than the students of the Faculty of Health Sciences. This may imply less effective strategies for coping with close interpersonal contact in the future, e.g. while working with patients. What is more, the students of the Faculty of Medicine obtained a significantly higher level of insecure attachment style than the students of the Faculty of Health Sciences.
Last but not least, female students demonstrated a higher level of emotional intelligence than their male counterparts, and this result only confirms the common belief that females are more sensitive to non-verbal communication and emotions than males [21]. When we take under consideration the level of emotional intelligence inside faculties, there is no difference between males and females.

Analysis of the level of emotional intelligence taking into account attachment style has shown that those with Secure Attachment Style, regardless of their faculty, have a higher level of emotional intelligence. According to Bartholomew, those demonstrating RQ - Insecure Attachment Style have difficulties establishing close, intimate relationships and avoid social contact. Moreover, they tend to be shy, sensitive, self-critical and manifest an intense fear of being rejected. They avoid getting into close, intimate relationships, because they may perceive others as inaccessible and insensitive to their care and support needs. Such persons seem to be imprisoned in the paradox of their desire for being in a close relationship and the fear of it [14].

It is thought that the Secure Attachment Style, as well as a high level of emotional intelligence, is connected with well-being and mental health. They reduce the risk of developing adaptive difficulties and disorders. It seems that a doctor equipped with such a tool as emotional intelligence and the Secure Attachment Style can get into a more constructive and corrective relationship with a patient. The ability of reacting adequately to a patient's emotional behavior or setting clear boundaries may prevent one from burnout [22]. 
It may be intuitively presumed that emotional intelligence and the Secure Attachment Style can be correlated with the field of studying medical or healthcare sciences, as well as constitute main factors to consider when choosing a career that complies with students' predispositions.

In addition, medical studies also provide an opportunity for developing interpersonal skills and getting into relationships with others. The motivation behind the choice of such a specific field of study is worth further consideration and research.

Another important matter is the range of opportunities that are to be provided by the university in the period of training and which are aimed at developing students' interpersonal skills and getting into relationships with others.

After analyzing the results of this research, the authors ask whether the reality matches the above presumptions, but it seems this is not always the case.

\section{Limitations of the study}

Our study presents a range of limitations, e.g. the evidence does not propose a consistent clarification of the link between emotional intelligence and attachment styles for the entire representation of Medical University students. In the research, only students of the Pomeranian Medical University in Szczecin participated. Attempts to assess the development of psychological adaptation to the medical profession in the future should be based on a larger research population.

\section{Conclusions}

Medical students shall be introduced to psychological prevention with special emphasis on developing emotional relations with others.

Source of funding: This work was funded by the authors' own resources.

Conflict of interest: The authors declare no conflict of interests.

\section{References}

1. Beach MC, Inui T. Relationship-centered care - a constructive reframing. J Gen Intern Med 2006; 21(Suppl. 1): S3-S8.

2. Mayer JD, Salovey P, Caruso DR. Emotional intelligence: theory, findings, and implications. Psych Inq 2004; 15: 197-215.

3. Landa JMA, Lopez-Zafra E, Berrios Martos MP, et al. The relationship between emotional intelligence, occupational stress and health in nurses: a questionnaire survey. Int J Nurs Stud 2008; 45(6): 888-901.

4. McCallin A, Bamford A. Interdisciplinary teamwork: is the influence of emotional intelligence fully appreciated? J Nurs Manag 2007; 15(4): 386-391.

5. Morrison J. The relationship between emotional intelligence competencies and preferred conflict-handling styles. J Nurs Manag 2008; 16(8): 974-983.

6. Gueleryuez G, Gueney S, Aydin EM, et al. The mediating effect of job satisfaction between emotional intelligence and organisational commitment of nurses: a questionnaire survey. Int J Nurs Stud 2008; 45(11): 1625-1635.

7. Sener E, Demirel O, Sarlak K. The effect of the emotional intelligence on job satisfaction. Stud Health Technol Inform 2009; 146: 710-711.

8. Landa JMA, Pulido Martos M, Lopez-Zafra E. Emotional intelligence and personality traits as predictors of psychological well-being in spanish undergraduates. Social Behavior and Personality 2010; 38(6): 783-793.

9. Weng H-C, Steed JF, Yu S-W, et al. The effect of surgeon empathy and emotional intelligence on patient satisfaction. Adv Health Sci Educ Theory Pract 2011; 16(5): 591-600.

10. Todres M, Tsimtsiou Z, Stephenson A, et al. The emotional intelligence of medical students: an exploratory cross-sectional study. Med Teach 2010; 32(1): E42-E48, doi: 10.3109/01421590903199668.

11. Stratton TD, Saunders JA, Elam CL. Changes in medical students' emotional intelligence: an exploratory study. Teach Learn Med 2008; 20(3): 279-284.

12. Weng H-C, Chen H-C, Chen H-J, et al. Doctors' emotional intelligence and the patient doctor relationship. Med Educ 2008; 42(7): 703-711.

13. Bowlby J. Attachment and Loss. Vol. III. Loss: sadness and depression. Basic Books; 1982. Available from URL: http://www.abebe.org. $\mathrm{br} / \mathrm{wp}$-content/uploads/John-Bowlby-Loss-Sadness-And-Depression-Attachment-and-Loss-1982.pdf.

14. Bartholomew K, Shaver PR. Methods of assessing adult attachment: do they converge? In: Simpson JA, Rholes WS, eds. Attachment theory and close relationships. New York: Guilford Press; 1998: 25-45. Available from URL: https://s3.amazonaws.com/academia.edu.documents/30025387/bartholomew98.pdf?AWSAccessKeyId=AKIAIWOWYYGZ2Y53UL3A\&Expires $=1505122213 \&$ Signature=0TPqDHoc7mK UbDB0pRmASH\%2Builg\%3D\&response-content-disposition=inline\%3B\%20filename\%3DMethods_of_assessing_adult_attachment.pdf.

15. Mikulincer M, Birnbaum G, Woddis D, et al. Stress and accessibility of proximity-related thoughts: exploring the normative and intraindividual components of attachment theory. J Pers Soc Psychol 2000; 78(3): 509-523.

16. Waters E, Weinfield NS, Hamilton CE. The stability of attachment security from infancy to adolescence and early adulthood: general discussion. Child Dev 2000; 71(3): 703-706.

17. Sauer EM, Lopez FG, Gormley B. Respective contributions of therapist and client adult attachment orientations to the development of the early working alliance: a preliminary growth modeling study. Psychother Res 2003; 13: 371-382.

18. Leiper R, Casares P. An investigation of the attachment organization of clinical psychologists and its relationship to clinical practice. $B r$ J Med Psychol 2000; 73(4): 449-464.

19. Dozier M, Cue KL, Barnett L. Clinicians as caregivers: role of attachment organization in treatment. J Consult Clin Psychol 1994; 62(4): 793-800.

20. Schutte NS, Malouff JM, Hall LE, et al. Development and validation of a measure of emotional intelligence. Personality and Individual Differences 1998; 25(2): 167-177.

21. Mayer JD, Hanson E. Mood-congruent judgment over time. Personality and Social Psychology Bulletin 1995; 21(3): 237-244, doi: https://doi.org/10.1177/0146167295213005.

22. Denham SA. The emotional basis of learning and development in early childhood education. Lawrence Erlbaum Associates Publishers, 2006. Available from URL: http://denhamlab.gmu.edu/Publications\%20PDFs/Denham\%202005.pdf.

Tables: 3

Figures: 1

References: 22

Received: 04.04.2017

Revised: 01.05.2017

Accepted: 06.06.2017
Address for correspondence:

Maciej Walkiewicz, PhD

Katedra Psychologii GUMed

ul. Tuwima 15, 80-210 Gdańsk, Polska

Tel.: +48 58 349-15-55

E-mail: walkiewicz@gumed.edu.pl 